\section{Journal of Anatolian Environmental and Animal Sciences (Anadolu Çevre ve Hayvancılık Bilimleri Dergisi) \\ Doi: https://doi.org/10.35229/jaes.635302}

\title{
Optimization of Veneer Drying Temperature for the Best Mechanical Properties of Plywood via Artificial Neural Network
}

\author{
Şükrü ÖZŞAHİN*1 $\quad$ Aydın DEMİR ${ }^{2} \quad$ İsmail AYDIN ${ }^{2}$ \\ ${ }^{1}$ Karadeniz Technical University, Department of Industrial Engineering Kanuni Campus, 61080 Trabzon, Turkey. \\ ${ }^{2}$ Karadeniz Technical University, Department of Forest Industry Engineering Kanuni Campus, 61080 Trabzon, Turkey. \\ *(D): https://orcid.org/0000-0001-8216-0048, (iD: https://orcid.org/0000-0003-4060-2578, (D: https://orcid.org/0000-0003-0152-7501
}

How to cite: Özsahin, S., Demir, A. \& Aydin, İ. (2019). Optimization of Veneer Drying Temperature for the Best Mechanical Properties of Plywood via Artificial Neural Network. Anatolian Env. and Anim. Sciences, 4(4), 589-597.

Atıf yapmak için: Özşahin, Ş., Demir, A. \& Aydin, İ. (2019). Kontrplakların En İyi Mekanik Özellikleri için, Yapay Sinir Ağları ile Kaplama Kurutma Sicaklığının Optimizasyonu. Anadolu Çev. ve Hay. Dergisi, 4(4), 589-597.

\begin{abstract}
The drying of veneer is an essential part of the veneer-producing process to aid the gluing during the manufacture of the plywood and laminated veneer lumber. Determining the optimum veneer drying temperature without decreasing of mechanical properties is also very important from industrial viewpoint. Due to the high drying costs, increased temperatures are being used commonly in plywood industry to reduce the overall drying time and increase capacity. However, high drying temperatures can alter some physical, mechanical and chemical characteristics of wood and cause some drying-related defects. In this study, it was aimed to predict the optimum drying temperature for alder and scots pine veneers via artificial neural network modelling for optimum mechanical properties. Therefore, mechanical strength values of plywood panels manufactured from alder and scots pine veneers were dried at temperatures of $110,130,150,170,190$ and $210^{\circ} \mathrm{C}$. Shear strength, bending strength and modulus of elasticity of the plywood panels were experimentally determined according to EN 314-1 and EN 310 standards. Then, the mechanical strength values based on veneer drying temperatures are subjected to prediction by artificial neural network modelling. As a results of this study, the optimum drying temperature values were obtained as 165,162 and $161^{\circ} \mathrm{C}$ in Scots pine plywood and 190,195 and $196^{\circ} \mathrm{C}$ in alder plywood, for best shear strength, bending strength and modulus of elasticity values, respectively.
\end{abstract}

Keywords: Alder, artificial neural network, mechanical properties, scots pine, veneer dying temperature.

\section{Kontrplakların En İyi Mekanik Özellikleri için, Yapay Sinir Ağları ile Kaplama Kurutma Sıcaklığının Optimizasyonu}

Öz: Kaplama kurutma işlemi, kontrplak ve LVL üretimi esnasında, tutkallama işlemini kolaylaştıran, kaplama üretiminin önemli parçalarından biridir. Yüksek kurutma maliyetleri nedeniyle, genel kurutma süresini azaltmak ve kapasiteyi artırmak için kontrplak endüstrisinde yaygın olarak yüksek sıcaklıklar kullanılmaktadır. Ancak, yüksek kurutma sıcaklıkları, ahşabın bazı fiziksel, mekanik ve kimyasal özelliklerini etkilemektedir ve kurumaya bağlı olarak bazı kusurlara neden olmaktadır. Bu çalışmada, yapay sinir ağları yardımıyla kurulan modellerle, en yüksek mekanik özellikleri sağlayan optimum kurutma sıcaklıklarının, kızılağaç (Alnus glutinosa subsp. barbata) ve sarıçam (Pinus slyvestris) kaplamaları için tahmin edilmesi amaçlanmıştır. Bu nedenle, kontrplak üretiminden önce kaplamalar, 110, 130, 150, 170,190 ve $210{ }^{\circ} \mathrm{C}$ sıcaklıklarda kurutulmuştur. Üretilen kontrplak levhaların çekme-makaslama direnci; TS EN 314-1, eğilme direnci ve elastikiyet modülü; TS EN 310 standartlarına göre belirlenmiştir. Daha sonra, mekanik direnç değerleri kaplama kurutma sıcaklıklarına bağlı olarak, yapay sinir ağları modellemesi ile tahmin edilmiştir. Çalışmanın sonucunda, en yüksek çekme-makaslama direnci, eğilme direnci ve elastikiyet modülü değerlerini veren en iyi kurutma sıcaklığı değerleri, sarıçam kontrplaklarında sırasıyla, 165,162 ve $161{ }^{\circ} \mathrm{C}$, kızılağaç kontrplaklarında ise, sırasıyla 190 , 195 ve $196^{\circ} \mathrm{C}$ sıcaklıklardan elde edilmiştir. 


\section{INTRODUCTION}

Plywood is a wood composite with good physical and mechanical properties and can be used for different applications such as the manufacturing of furniture, musical instruments, means of transportation, packings, sporting goods, as well as in constructions (Bekhta \& Salca, 2018). Its production in the World and Europe in 2016 exceeded 159 and 8 million cubic meters, respectively (FAO, 2018). European Union (EU) imports of panels (mainly plywood) increased $9 \%$ to Euro 2.79 billion in 2017. This follows a 3\% rise in 2016 and an $11 \%$ increase in 2015. Most of this gain was due to a rise in plywood imports from Russia and other Eastern European countries. The value of EU plywood imports from China and tropical countries was generally stable or declining in 2017 (Industry News \& Markets, 2018).

Drying veneer sheets is an essential part of the veneer manufacturing process. Veneer drying often becomes a production bottleneck because of inefficient equipment and methods. The purpose of veneer drying is to reduce its moisture content to a range suitable for gluing (Aydin \& Colakoglu, 2008). Drying process accounts for some 70 percent of the thermal energy consumed in plywood production and approximately 60 percent of the mill's total energy requirement. Although drying temperatures of between $90-160^{\circ} \mathrm{C}$ may be considered normal, increased temperatures are being used to reduce the overall drying time and increase capacity (FAO, 1990). Reductions in drying time and energy consumption offer the wood industries a great potential for economic benefit (Aydin, 2014). It was concluded that the high-temperature drying practice can save energy and drying time by 44 and $25 \%$, respectively, in comparison with the conventional temperature drying (Theppaya \& Prasertsan, 2004). Also, the economic benefits of quick drying of veneers at high temperature, this process can be effective on some mechanical, physical and chemical properties of wood (Ozsahin \& Aydin, 2014).

Determination of the optimum veneer drying temperature without loss of mechanical strength is also very important from industrial view point. For this aim, a lot of temperature values need to be tested to determine the optimum values that cause the loss of much time and energy and high costs. Therefore, it is important to find more economic methods providing desirable results concerning technological properties (Demirkir et al., 2013). Artificial neural networks (ANNs) have been widely used in the field of wood (Esteban et al., 2011). The neural network most commonly used is the multilayer perception, whose nature as a universal function approximation makes it a powerful tool for modelling complex relations between variables (Fernandez et al., 2012). ANNs are capable of processing information in a parallel distributed manner, learning complex cause-and-effect relationships between input and output data, dealing with nonlinear problems, generalizing from known tasks or examples to unknown tasks. ANNs are good for tasks involving incomplete data sets, fuzzy or incomplete information, and for highly complex and illdefined problems, where people usually decide on an intuitional basis. Moreover, they can be faster, cheaper and more adaptable than traditional methods (Ceylan, 2008; Ozsahin \& Aydin, 2014).

This study is aimed to predict the optimum drying temperature for alder and Scots pine veneers via artificial neural network for best mechanical properties by using experimental data. The main purpose was to obtain the intermediate values not measured from the experimental study by artificial neural network modelling and to estimate the optimum temperature values for each wood species giving the highest mechanical strength values.

\section{MATERIAL and METHODS}

Scots pine (Pinus slyvestris) and alder logs (Alnus glutinosa subsp. barbata) were used in this study. The logs were obtained from Trabzon region. While the alder logs were peeled freshly, scots pine logs were steamed for 12-16 hours before veneer production. A rotary type peeler (Valette \& Garreau - Vichy, France) with a maximum horizontal holding capacity of $800 \mathrm{~mm}$ was used for veneer manufacturing and rotary cut veneer sheets with dimensions of $500 \times 500 \mathrm{~mm}$ by $2 \mathrm{~mm}$ were clipped. Vertical opening was $0.5 \mathrm{~mm}$ and horizontal opening was $85 \%$ of the veneer thickness in veneer manufacturing process. After rotary peeling, spruce and beech veneer sheets were divided into six groups. The veneers were oven-dried at $110^{\circ} \mathrm{C}, 130^{\circ} \mathrm{C}, 150^{\circ} \mathrm{C}, 170^{\circ} \mathrm{C}$, $190^{\circ} \mathrm{C}$ and $210^{\circ} \mathrm{C}$ for $5-7 \%$ moisture content in a laboratory scale jet veneer dryer (manufactured by Hildebrand Holztechnik GmbH).

Three-ply-plywood panels with $6 \mathrm{~mm}$ thick were manufactured by using urea formaldehyde (UF) glue resin with $55 \%$ solid content. The formulations of adhesive mixture are given in Table 1. Two replicate panels were manufactured for all test groups. Approximately $160 \mathrm{~g} / \mathrm{m} 2$ adhesive mixture was spread on single surfaces of veneers by using a four roller gluing machine. In the manufacturing of plywood panels, hot pressing time was 6 minutes, press pressure were 1.2 MPa for alder and $0.8 \mathrm{MPa}$ for scots pine, and press temperature was $110^{\circ} \mathrm{C}$.

Table 1. Formulations of adhesive mixtures used for the manufacturing of plywood panels.

\begin{tabular}{ll}
\hline Ingredients of Adhesive & Parts by weight \\
\hline UF resin (with $55 \%$ solid) & 100 \\
Wheat flour & 30 \\
Hardener $\left(\mathrm{NH}_{4} \mathrm{Cl}\right.$ with $15 \%$ concentration) & 10 \\
\hline
\end{tabular}

Shear strength test was carried out for plywood panels manufactured according to EN 314-1 (1998) standard. Thirty samples were used for the evaluation of plywood shear strength. Before the shear strength tests, samples obtained 
from the panels manufactured with UF glue were immersed for 24 hours in water at $20 \pm 3^{\circ} \mathrm{C}$. Bending strength and modulus of elasticity tests was carried out for plywood panels manufactured according to EN 310 (1993) standard. Twelve samples were used for the evaluation of plywood bending strength and modulus of elasticity.

ANN was used to predict the shear strength, bending strength and modulus of elasticity values in response to the other veneer drying temperatures not obtained from this experimental study. In this way, it was aimed to reveal the optimum veneer drying temperature for each wood species to obtain the highest shear strength, bending strength and modulus of elasticity. In the ANN modelling for the present work; wood species and drying temperatures were considered as the prime processing variables. The proposed ANN models was designed by software developed using the MATLAB Neural Network Toolbox. The data were obtained from the experimental study. To examine the effects of wood species and drying temperatures on shear strength, bending strength and modulus of elasticity; the experimental data were grouped into training data and test data. Among these data, 8 samples were selected for ANN training process, while the remaining 4 samples were used to verify the generalization capability of ANN. The data sets used in the training and prediction models are shown in Table 2. The shear strength, bending strength and modulus of elasticity results obtained experimentally also presented in Table 2.
The obtained predicted values as a result of the testing process were compared with the real (measured) values. The models providing the best prediction values with respect to the root mean-square error (RMSE) ratio, calculated with Eq. 1, the mean absolute percentage error (MAPE) ratio, calculated with Eq. 2 and coefficient of determination $\left(\mathrm{R}^{2}\right)$ with Eq. 3 was chosen as the prediction models.

$$
\begin{aligned}
& \mathrm{RMSE}=\sqrt{\frac{1}{N} \sum_{i=1}^{N}\left(t_{i}-t d_{i}\right)^{2}} \\
& \mathrm{MAPE}=\frac{1}{N}\left(\sum_{i=1}^{N}\left[\left|\frac{t_{i}-t d_{i}}{t_{i}}\right|\right]\right) \times 100 \\
& \mathrm{R}^{2}=1-\frac{\sum_{i=1}^{N}\left(t_{i}-t d_{i}\right)^{2}}{\sum_{i=1}^{N}\left(t_{i}-\bar{t}\right)^{2}}
\end{aligned}
$$

In Equations 1, 2 and 3, $t_{i}$ is the actual output values, $t d_{i}$ is the neural network predicted values, and $N$ is the

\begin{tabular}{|c|c|c|c|c|c|c|c|c|c|c|}
\hline \multicolumn{11}{|c|}{ Training Data } \\
\hline \multirow{2}{*}{ Wood Species } & \multirow{2}{*}{ Drying Temperature $\left({ }^{\circ} \mathrm{C}\right)$} & \multicolumn{3}{|c|}{ Shear Strength $\left(\mathrm{N} / \mathrm{mm}^{2}\right)$} & \multicolumn{3}{|c|}{ Bending Strength $\left(\mathrm{N} / \mathrm{mm}^{2}\right)$} & \multicolumn{3}{|c|}{ Modulus of Elasticity $\left(\mathrm{N} / \mathrm{mm}^{2}\right)$} \\
\hline & & Actual & Predicted & Error (\%) & Actual & Predicted & Error (\%) & Actual & Predicted & Error (\%) \\
\hline Scots pine & 110 & 1.342 & 1.342 & 0.002 & 65.733 & 65.753 & -0.031 & 4868.228 & 4870.060 & -0.038 \\
\hline Scots pine & 150 & 1.447 & 1.448 & -0.015 & 87.611 & 87.586 & 0.029 & 5509.160 & 5508.783 & 0.007 \\
\hline Scots pine & 170 & 1.719 & 1.719 & 0.002 & 88.231 & 88.228 & 0.004 & 5518.530 & 5518.553 & 0.000 \\
\hline Scots pine & 210 & 1.006 & 1.006 & -0.002 & 56.018 & 56.013 & 0.008 & 4618.743 & 4618.774 & -0.001 \\
\hline Alder & 130 & 1.212 & 1.212 & 0.042 & 63.057 & 63.328 & -0.430 & 4360.011 & 4377.383 & -0.398 \\
\hline Alder & 150 & 1.404 & 1.403 & 0.041 & 65.413 & 65.063 & 0.536 & 4424.940 & 4406.832 & 0.409 \\
\hline Alder & 190 & 1.888 & 1.888 & -0.016 & 71.250 & 71.331 & -0.114 & 4878.719 & 4879.752 & -0.021 \\
\hline \multirow[t]{3}{*}{ Alder } & 210 & 1.181 & 1.181 & -0.012 & 58.839 & 58.835 & 0.006 & 3701.773 & 3702.047 & -0.007 \\
\hline & MAPE & & 0.017 & & & 0.145 & & & 0.110 & \\
\hline & RMSE & & 0.000 & & & 0.160 & & & 8.905 & \\
\hline \multicolumn{11}{|c|}{ Testing Data } \\
\hline & \multirow{2}{*}{ Drying Temperature $\left({ }^{\circ} \mathrm{C}\right)_{-}$} & \multicolumn{3}{|c|}{ Shear Strength $\left(\mathrm{N} / \mathrm{mm}^{2}\right)$} & \multicolumn{3}{|c|}{ Bending Strength $\left(\mathrm{N} / \mathrm{mm}^{2}\right)$} & \multicolumn{3}{|c|}{ Modulus of Elasticity $\left(\mathrm{N} / \mathrm{mm}^{2}\right)$} \\
\hline & & Actual & Predicted & Error (\%) & Actual & Predicted & Error (\%) & Actual & Predicted & Error (\%) \\
\hline Scots pine & 130 & 1.391 & 1.343 & 3.460 & 77.073 & 77.058 & 0.019 & 5201.858 & 5164.226 & 0.723 \\
\hline Scots pine & 190 & 1.252 & 1.137 & 9.177 & 62.548 & 63.003 & -0.728 & 5081.412 & 5128.929 & -0.935 \\
\hline Alder & 110 & 1.257 & 1.290 & -2.626 & 64.471 & 62.341 & 3.303 & 4336.573 & 4371.079 & -0.796 \\
\hline Alder & 170 & 1.426 & 1.485 & -4.089 & 65.550 & 67.787 & -3.413 & 4499.033 & 4520.922 & -0.487 \\
\hline \multicolumn{2}{|r|}{ MAPE } & \multicolumn{3}{|c|}{4.838} & \multicolumn{3}{|c|}{1.866} & \multicolumn{3}{|c|}{0.735} \\
\hline \multicolumn{2}{|r|}{ RMSE } & \multicolumn{3}{|c|}{0.071} & \multicolumn{3}{|c|}{1.561} & \multicolumn{3}{|c|}{36.551} \\
\hline
\end{tabular}
number of objects.

Table 2. Training and testing data set and shear strength, bending strength and modulus of elasticity prediction models results.

Figure 1 shows the ANN models containing one input layer, one hidden layers and one output layer. The selected ANN models represents the prediction models that produced the closest values to the measured values for the shear strength, bending strength and modulus of elasticity. The wood species and drying temperatures were used as the input variables, while the shear strength, bending strength and modulus of elasticity values was used as the output variable in the ANN models. The processing element numbers (neurons) of the hidden layers were 4, 3 and 3 for the models in Figure 1.

A feed forward and back propagation multilayer ANN was used for solving problems, and the network training and testing was carried out using the MATLAB 
software package. In this study, the hyperbolic tangent sigmoid function (tansig) and the linear transfer function (purelin) were used as the activation transfer functions, the levenberg marquardt algorithm (trainlm) was used as the training algorithm, the gradient descent with a momentum back propagation algorithm (traingdm) was used as the learning rule, and the mean square error (MSE) with Eq. 4 was used as the performance function.
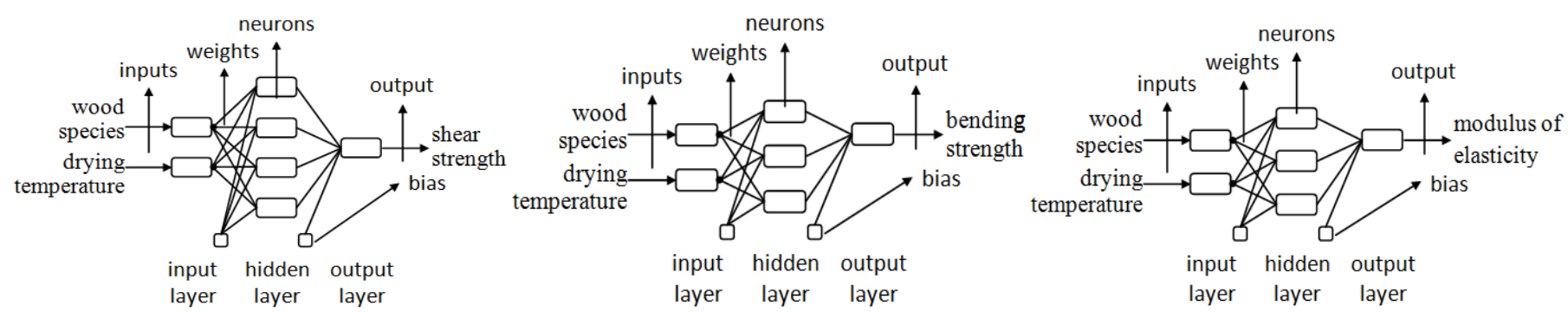

Figure 1. The ANN architecture selected as the prediction models.

$$
\operatorname{MSE}=\frac{1}{N} \sum_{i=1}^{N}\left(t_{i}-t d_{i}\right)^{2}
$$

Where, $t_{i}$ is the actual output (targeted values), $t d_{i}$ is the neural network output (predicted values), and $N$ is the total number of training patterns.

To ensure an equal contribution of each parameter in the models, the training and test were normalized $(-1,1$ range) due to the use of the hyperbolic tangent sigmoid function in the models and network, which allowed the data to be translated into the original value, with a reverse normalizing process for the interpretation of the results. The normalization (scaling) operations were carried out by using Eq. 5.

$$
X_{\text {norm }}=2 \times \frac{X-X_{\text {min }}}{X_{\text {max }}-X_{\text {min }}}-1
$$

Where, $X_{\text {norm }}$ is the normalized value of a variable $X$ (real value of the variable), and $X_{\max }$ and $X_{\min }$ are the maximum and minimum values of $X$, respectively.

\section{RESULTS and DISCUSSION}

Experimental Results: The shear strength, bending strength and modulus of elasticity values of plywood panels manufactured with UF glue were presented in Table 2, based on veneer wood species and veneer drying temperatures.

As can be seen from Table 2, the highest shear strength, bending strength and modulus of elasticity values were obtained experimentally from $170^{\circ} \mathrm{C}$ for Scots pine plywood, while $190^{\circ} \mathrm{C}$ drying temperature yielded the best shear strength, bending strength and modulus of elasticity values both for alder plywood.

Artificial Neural Network Results: Changes of shear strength, bending strength and modulus of elasticity depending on the veneer drying temperature were modelled with obtained network parameters. The amount of error variation depending on iteration of the selected ANN was shown in Figure 2.

Figure 3 shows the relationship between the real values and calculated values obtained by the prediction models. The comparative plots of these values are given in Figure 4.
Shear strength

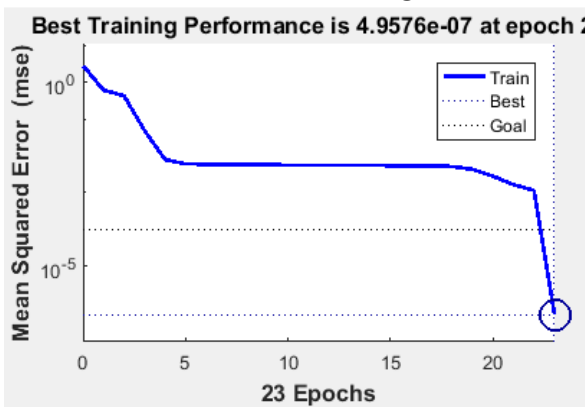

Bending strength

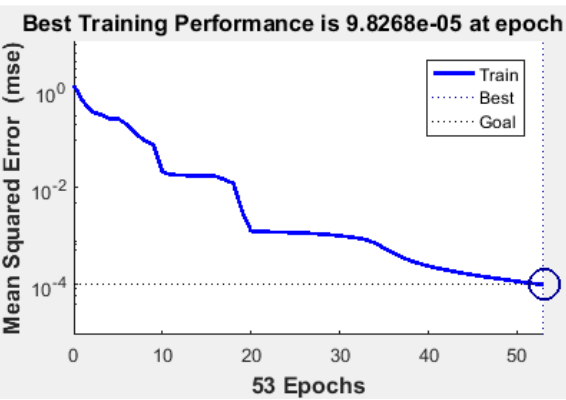

Modulus of elasticity

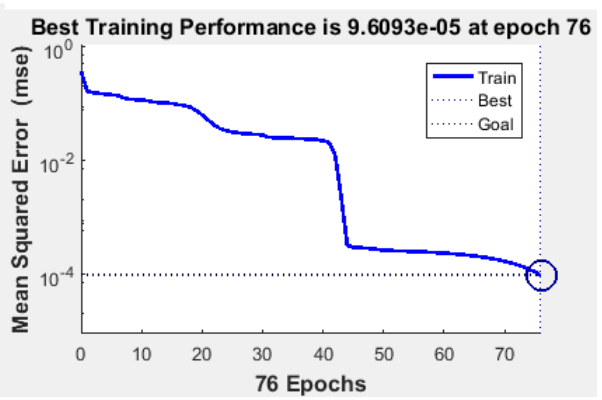

Figure 2. A plot of error variation depending on iteration of the ANNs. 

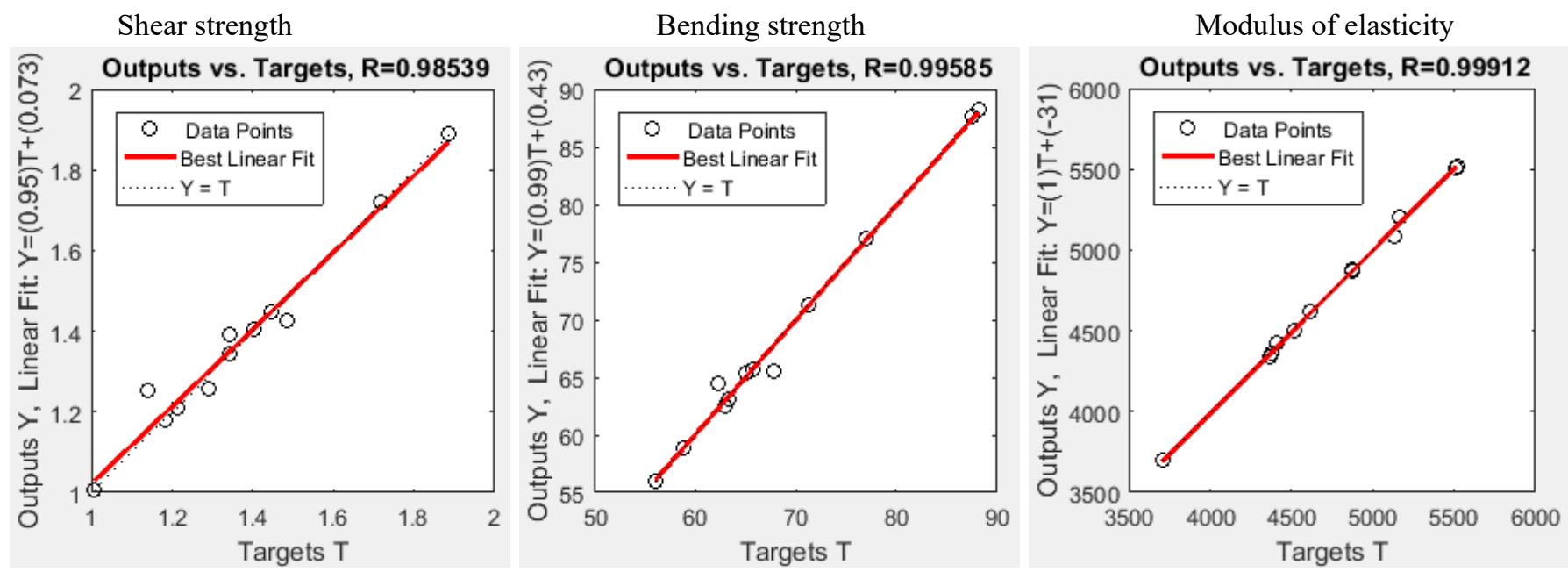

Figure 3. The relationship between experimental results and ANN predicted results.

Shear strength

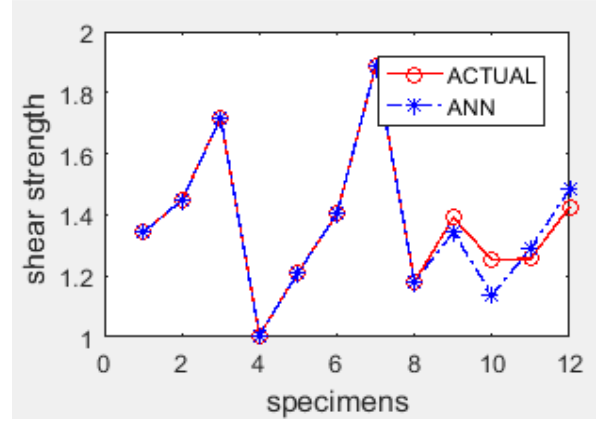

Bending strength

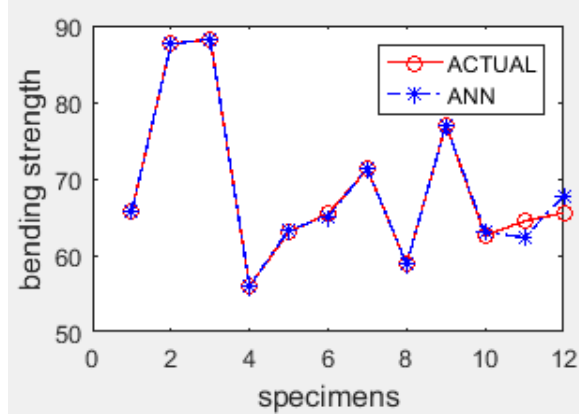

Modulus of elasticity

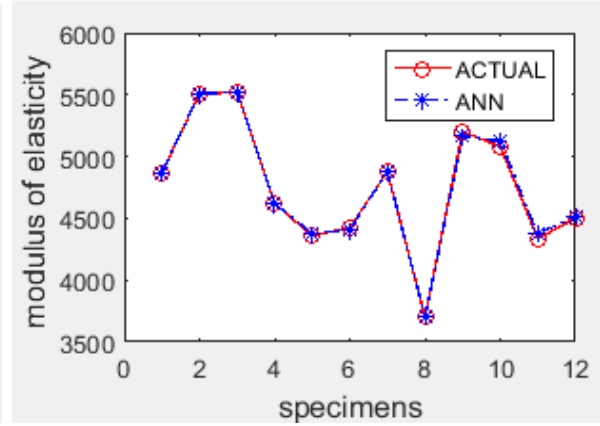

Figure 4. The comparison of the real and calculated values.

In order to assess the validity of the networks and their accuracy, it is often useful to perform regression analysis between the network response and the corresponding target. The regression curves of the output variables for the experiment and ANN data set are shown in Figure 3 (shear strength, $\mathrm{R}=0.98539$; bending strength, $\mathrm{R}=0.99585$; modulus of elasticity, $\mathrm{R}=0.99912$ ). As the correlation coefficients approach 1, prediction accuracy increases and indicates good agreement between the experimental results and the models predication. This value supports the applicability of using ANNs in the present study.

Comparisons of the results between the outcomes of ANN modelling and experimental values for the shear strength, bending strength and modulus of elasticity values are plotted in Figure 4. The results of graphic comparisons showed similarities between the experimental study and the ANN models and supported the reliability of the models.

The results indicate a consistent agreement between the outcomes of the ANN modelling and the experimental results. MAPE was used to evaluate the performance of the proposed ANN in the prediction technique. The maximum absolute percentage errors (MAPE) for shear strength, bending strength and modulus of elasticity were $0.017,0.145$ and $0.110 \%$ for training and $4.838 \%, 1.866 \%$ and 0.735 $\%$ for testing, respectively. These levels of error are satisfactory for the shear strength, bending strength and modulus of elasticity. As seen from the results, the ANN approach has a sufficient accuracy rate for the prediction of shear strength, bending strength and modulus of elasticity values of plywood.

The intermediate values not obtained from the experimental study for shear strength, bending strength and modulus of elasticity were predicted from the designed ANN modelling. The shear strength, bending strength and modulus of elasticity values predicted by the ANN models for different drying temperature are shown in Figure 5, 6 and 7.

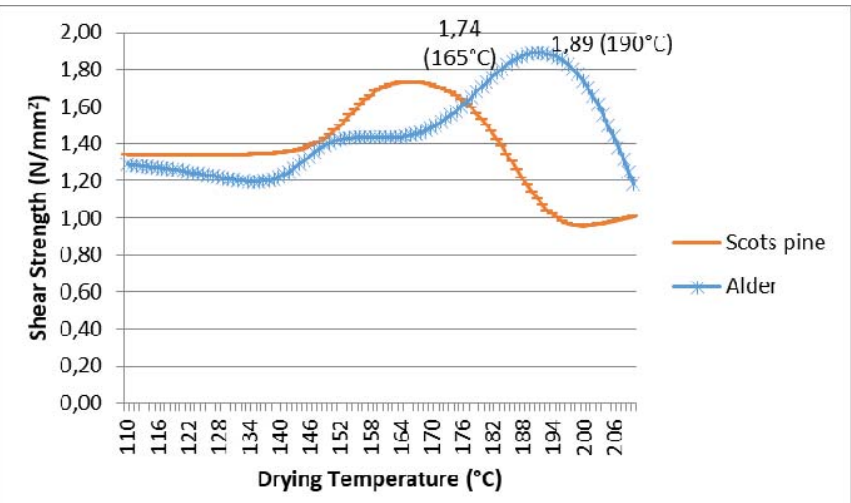

Figure 5. The change of shear strength with increasing drying temperature. 


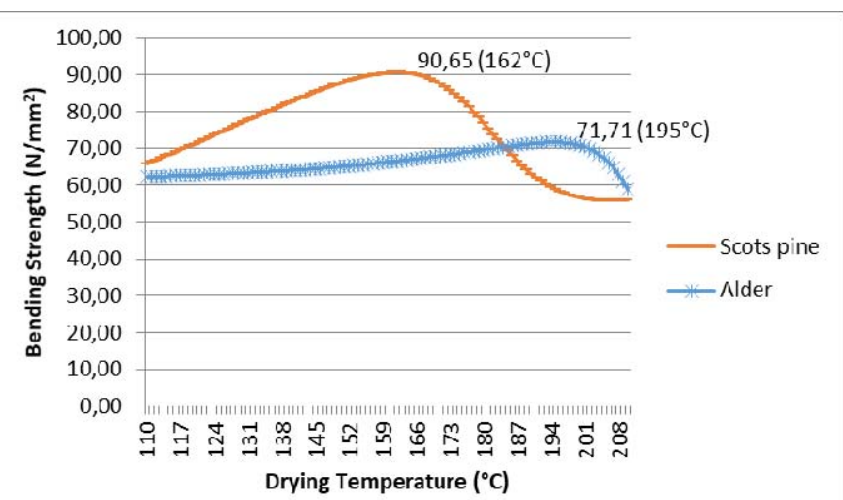

Figure 6. The change of bending strength with increasing drying temperature.

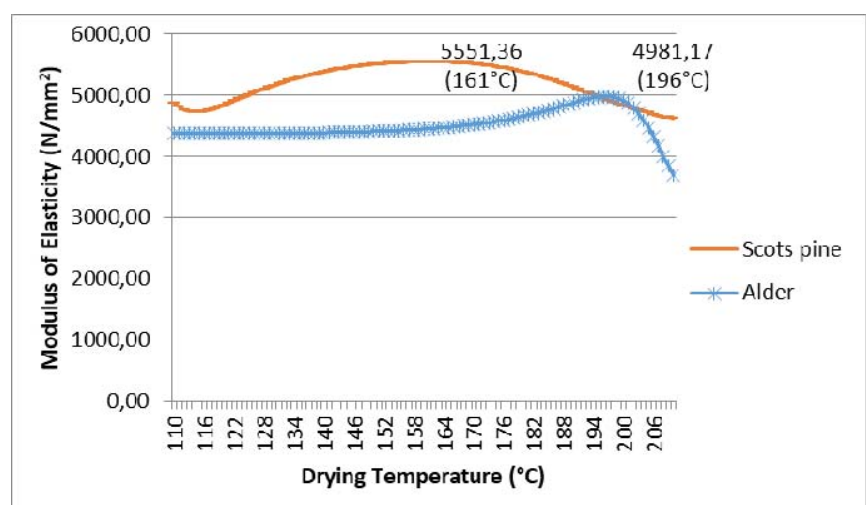

Figure 7. The change of modulus of elasticity with increasing drying temperature.

According to Figure 5, 6 and 7, the optimum drying temperature values yielded the highest shear strength, bending strength and modulus of elasticity were found as 165,162 and $161^{\circ} \mathrm{C}$ for Scots pine and 190,195 and $196^{\circ} \mathrm{C}$ for alder, respectively. Plywood manufacturers prefer veneer to be dried at the highest possible temperature for a short time, without having the veneer degraded by excessive heat (Shen, 1958).Drying temperatures between $90-160^{\circ} \mathrm{C}$ are considered normal in veneer drying process, but the use of higher drying temperatures are giving rise to a reduction in drying time and increased capacity (FAO, 1990). On the other hand, high drying temperatures cause changes in the physical, mechanical and chemical characteristics of wood because of surface inactivation (Lehtinen et al., 1997; Sernek, 2002). In addition, veneer drying temperature affects the veneer-water relationships. Concerning this issue, Aydin (2014) studied the effects of veneer drying at high temperature on equilibrium moisture content, and reported that high temperature veneer drying caused a significant decrease in equilibrium moisture content values of plywood produced from beech, spruce and alder veneers. The waterabsorbing capacity of veneer is reduced by increasing the drying temperature with a constant time, or by increasing the drying time at a constant temperature. The reduced waterabsorbing capacity of the veneer could be a contributing factor in producing inferior glue bonds because of reduction in wettability of the veneer by the glue (Currier, 1958). It was also indicated in literature that, during a drying process, significant reduction in bonding ability occurs at the end of drying, when the evaporative cooling effect decreases and the wood surface temperature approaches that of the air in the dryer (Suchsland \& Stevens, 1968). However, severe surface inactivation occurs at the drying temperature of $160^{\circ} \mathrm{C}$ and higher (Christiansen, 1990). According to the ANN models used in the present study, the decreases in mechanical strength values with increasing drying temperature has also been started from about $165-170^{\circ} \mathrm{C}$ for Scots pine and 195 $200^{\circ} \mathrm{C}$ for alder (See Figure 5-7).

Christiansen (1990) stated that surface inactivation is more prevalent in some wood species than in others and the highest safe drying temperatures for avoiding inactivation in wood varies with species. For example, southern pine was indicated to be the most susceptible species for inactivation, followed by ponderosa pine, then douglas-fir, western white pine and larch. Therefore, it can be considered normal that the optimum veneer drying temperature values (presenting the highest mechanical strength values) were different for Scots pine and alder plywood panels in the present study. Ozsahin \& Aydin (2014) determined that the optimum drying temperature values yielded the highest bonding strength were obtained as $169^{\circ} \mathrm{C}$ for urea formaldehyde and $125^{\circ} \mathrm{C}$ for phenol formaldehyde adhesive in beech plywood while $162^{\circ} \mathrm{C}$ for urea formaldehyde and $151^{\circ} \mathrm{C}$ for phenol formaldehyde in spruce plywood panels. Demirkir et al. (2013) found that optimum veneer drying temperature ranges giving the highest bonding strength values were determined as $154-160^{\circ} \mathrm{C}$ for panels with phenol formaldehyde. In this study, it was determined as $160-165^{\circ} \mathrm{C}$ for Scots pine plywood produced with urea formaldehyde. In a study conducted by Lehtinen (1998) on spruce plywood, it was also concluded that bending strength increased by $6.3-12 \%$ when the veneer drying temperature was increased from $110^{\circ} \mathrm{C}$ to $180^{\circ} \mathrm{C}$.

At ANN design, some experimental results were used for training and some others were used for testing (Table 2). On the other hand, some data values for the Scots pine samples dried at $190^{\circ} \mathrm{C}$ was not available in training set. However, the strength values for this temperature was available for alder samples (Table 2). It was stated in literature that, ANNs are capable of processing information in a parallel distributed manner, learning complex cause and effect relationships between input and output data, dealing with nonlinear problems, generalizing from known tasks or examples to unknown tasks. ANNs are good for tasks involving incomplete data sets, fuzzy or incomplete information, and for highly complex and ill-defined problems for which humans would usually decide on an intuitional basis. Moreover, they can be more adaptable than traditional methods and ANNs technology brings completely different concepts to computing (Ceylan, 2008). As a consequence, the knowledge of the neural network is spread overall the links in 
network with their weight values. So, the lack of some data in a trained ANN does not significantly affect the network to produce accurate information.

\section{CONCLUSIONS}

Increased temperatures are being used in plywood industry to reduce the overall drying time and increase capacity because of the high cost of drying process. However, high drying temperatures can cause some drying related defects. In the manufacturing of plywood, veneers should be dried as quickly as possible with high temperatures without losing mechanical properties. The optimum veneer drying temperature gives the highest mechanical strength values of plywood can be different depending on the wood species from which the veneers manufactured. These types of experimental studies need much time and high testing cost. Therefore, ANN modelling method can be used as a predictive method to determine the appropriate drying conditions for best mechanical properties. In the present study, the optimum drying temperatures for Scots pine and alder veneers were predicted by ANN modelling for best mechanical properties by using experimental data. As a results, the optimum drying temperature values were obtained as 165,162 and $161^{\circ} \mathrm{C}$ in Scots pine plywood and 190,195 and $196^{\circ} \mathrm{C}$ in alder plywood, for best shear strength, bending strength and modulus of elasticity values, respectively. It can be concluded from this study that the ANN method is reasonable for the modelling (the optimization) of shear strength, bending strength and modulus of elasticity at various drying temperature without needing the experimental study again and again.

\section{REFERENCES}

Aydin, I. (2014). Effects of veneer drying at high temperature and chemical treatments on equilibrium moisture content of plywood. Maderas: Ciencia $Y$ Tecnología, 16(4), 445-452.

Aydin, I. \& Colakoglu, G. (2008). Variations in bending strength and modulus of elasticity of spruce and alder plywood after steaming and high temperature drying. Mechanics of Advanced Materials and Structures, 15(5), 371-374.

Bekhta, P. \& Salca, E.A. (2018). Influence of veneer densification on the shear strength and temperature behavior inside the plywood during hot press. Construction and Building Materials, 162, 20-26.

Ceylan, I., (2008). Determination of drying characteristics of timber by using artificial neural networks and mathematical models. Drying Technology, 26(12), 1469-1476.

Christiansen, A.W. (1990). How overdrying wood reduces its bonding to phenol formaldehyde adhesives: a critical review of the literature, part I physical responses. Wood Fiber Science, 22(4), 441-459.

Currier, R.A. (1958). High drying temperatures-do they harm veneer. Forest Products Journal, 8(4), 128136.

Demirkir, C., Özsahin, Ş., Aydin I. \& Colakoglu, G. (2013). Optimization of some panel manufacturing parameters for the best bonding strength of plywood. International Journal of Adhesion and Adhesives, 46, 14-20.

EN 310. (1993). Wood based panels. Determination of modulus of elasticity in bending and of bending strength. European Standard.

EN 314-1. (1998). Plywood-bonding quality-part1: test methods, European Standard.

Esteban, L.G. Fernandez, F.G. \& Palacios, P. (2011). Prediction of plywood bonding quality using an artificial neural network. Holzforschung, 65(2), 209214.

Fernández, F.G., Esteban, L.G., Palacios, P., Navarro, N. \& Conde, M. (2008). Prediction of standard particleboard mechanical properties utilizing an artificial neural network and subsequent comparison with a multivariate regression model. Investigación agraria: Sistemas y recursos forestales, 17(2), 178187.

Industry News \& Markets. (2018). Wood Products Prices in Europe. The International Tropical Timber Organization (ITTO) Tropical Timber Market Report, U.S.

Lehtinen, M. (1998). Effects of manufacturing temperatures on the properties of plywood. Helsinki University of Technology. Laboratory of Structural Engineering and Building Physics, TRT Report No 92, Finland.

Lehtinen, M., Syrjänen, T. \& Koponen, S. (1997). Effect of Drying Temperature on Properties of Veneer. Helsinki University of Technology, Laboratory of Structural Engineering and Building Physics, Finland.

Ozsahin, S. \& Aydin, I. (2014). Prediction of the optimum veneer drying temperature for good bonding in plywood manufacturing by means of artificial neural network. Wood science and technology, 48(1), 5970.

Sernek, M. (2002). Comparative Analysis of Inactivated Wood Surfaces. Ph.D. Thesis, Faculty of the Virginia Polytechnic Institute and State University, Blacksburg, Virginia.

Shen, K.C. (1958). The Effects of Dryer Temperature, Sapwood and Heartwood, and Time Elapsing Between Drying and Gluing on The Gluing Properties of Engelmann Spruce Veneer, MSc Thesis, Faculty of Forestry, The University of British Columbia. 
Suchsland, O. \& Stevens, R.R. (1968). Gluability of Southern Pine Veneer Dried at High Temperatures, Forest Products Journal, 18(1), 38-42.

The Food and Agriculture Organization (FAO). (1990). Energy Conservation in the Mechanical Forest Industries: FAO Forestry Paper, Rome.

The Food and Agriculture Organization (FAO). (2018). FAOSTAT-FAO Statics Division-Production Quantity/Plywood. http://faostat3.fao.org/browse /F/FO/E.

Theppaya, T. \& Prasertsan, S. (2004). Optimization of Rubber Wood Drying by Response Surface Method and Multiple Contour Plots. Drying Technology, 22(7), 1637-1660.

\section{*Corresponding author's:}

Şükrü ÖZŞAHINN

Karadeniz Technical University, Department of Industrial Engineering Kanuni Campus, 61080 Trabzon, Turkey.

E-mail : sukru@ktu.edu.tr

ORCID : https://orcid.org/0000-0001-8216-0048

Phone : $+90(462) 3772084$

Fax : +90 (462) 3256482 